\title{
CHEMICAL DEFENSE OF Hymeniacidon heliophila (PORIFERA: HALICHONDRIDA) AGAINST TROPICAL PREDATORS
}

Suzi Meneses Ribeiro ${ }^{1,2}$, Éverson Miguel Bianco ${ }^{3,4}$, Ricardo Rogers ${ }^{1}$, Valéria Laneuville Teixeira ${ }^{1,3}$ and Renato Crespo Pereira ${ }^{1,3, *}$

${ }^{1}$ Universidade Federal Fluminense

Instituto de Biologia, Departamento de Biologia Marinha

(Outeiro de São João Baptista, s/nº, Caixa Postal 100.644, 24001-970, RJ, Brasil)

${ }^{2}$ Universidade Federal do Rio de Janeiro

Museu Nacional, Departamento de Invertebrados

(Quinta da Boa Vista s/nº, São Cristóvão, 20940-040, RJ, Brasil)

${ }^{3}$ Universidade Federal Fluminense

Instituto de Química, Pós-graduação em Química Orgânica

(Outeiro de São João Baptista, s/nº, 24020-150, Niterói, RJ, Brasil)

${ }^{4}$ Universidade Federal de Pernambuco

Departamento de Química Fundamental

(Av. Prof. Moraes Rego, 1.235, 50670-901 Recife, PE, Brasil).

*Corresponding author: renato.pereira@pq.cnpq.br

\section{A B S TR ACT}

Various benthic organisms have chemical defenses which reduce their predators' consumption. Although their efficiency may be noticed in many organisms, many of their effects are not wellknown yet. Multiple ecological roles of secondary metabolites are shown in some sponges, which may represent an adaptative advantage considering the high amount of energy used to produce these chemical compounds. The goal of this work was to investigate the defensive property of the extracts from the sponge Hymeniacidon heliophila against the tropical predators: hermit crabs (Calcinus tibicens), sea urchins (Lytechinus variegatus) and generalist fishes. Extracts obtained with $n$-hexane, ethyl acetate and acetone/methanol were used in assays and all of them were effective in reducing the consumption by $C$. tibicens; $n$-hexane extract reduced the consumption by $L$. variegatus; and medium polarity extracts reduced fish consumption. Either the variation in action or the multiple ecological roles of the extracts indicates that different types of compounds can be associated to the defensive system produced by $H$. heliophila.

\section{RESUMO}

Diversos organismos bênticos possuem defesas químicas que ajudam a diminuir a predação. Embora sua eficácia seja comprovada, muitos de seus efeitos são ainda desconhecidos. Múltiplas funções dos metabolitos secundários foram evidenciadas em algumas esponjas e isso pode representar uma vantagem adaptativa, considerando o alto valor energético gasto pelas espécies para produzí-los. O objetivo desse trabalho foi investigar as propriedades defensivas de extratos da esponja Hymeniacidon heliophila contra predadores tropicais: paguros (Calcinus tibicens), ouriços-do-mar (Lytechinus variegatus) e peixes generalistas. Extratos em $n$-hexano, acetato de etila e acetona/metanol foram usados nos ensaios e todos foram eficientes na redução do consumo por $C$. tibicen; extratos em $n$-hexano reduziram o consumo por L. variegatus; e extratos de média polaridade reduziram o consumo por peixes. A variação na ação ou as funções ecológicas múltiplas dos extratos indicam que diferentes tipos de substâncias podem ser associadas ao sistema defensivo produzido por Hymeniacidon heliophila.

Descriptors: Hymeniacidon heliophila, chemical defenses, predation, tropical predators.

Descritores: Hymeniacidon heliophila, defesas químicas, predação, predadores tropicais. 


\section{INTRODUCTION}

Sponges are a rich source of secondary metabolites, producing the most numerous and diversified compounds (BLUNT, 2009 and previous reviews) with wide spectrum of biological activities, such as cytotoxic, ichthyotoxic, anti-bacteria, antifungic and neurotoxic (e.g. FENICAL, 2006; MAYER et al., 2009). Many of these chemicals are also known to have various ecological roles, mainly as a defense against consumers in sponges from the tropical and temperate Pacific, Mediterranean and Caribbean (CIMINO et al., 1982; THOMPSON et al., 1985; PAWLIK et al., 1988; HERB et al., 1990; ROGERS; PAUL, 1991; DUFFY; PAUL 1992; PENNINGS et al., 1994; MCCLINTOCK et al., 1997).

In fact, many animals are known to eat sponges, including fishes (RANDALL; HARTMAN 1968), sea stars (MCCLINTOCK et al., 1994), polychaetes (PAWLIK, 1983) echinoids (SANTOS et al., 2002), and turtles (BJORNDAL, 1990). Other omnivorous invertebrates also can prey sponge tissue, as hermit crabs (pers. obs.). Therefore, these chemicals can be a response to this elevated consumption pressure.

Most of chemical ecological studies revealed that the function of sponge secondary metabolites is to deter predation by fishes (e.g. PAWLIK et al., 1995; WILSON et al., 1999; ASSMANN et al., 2000). However, these chemicals can also defend sponges against hermit crabs (WADDELL; PAWLIK, 2000a), and sea stars (WADDELL; PAWLIK, 2000b).

Despite the large literature about sponges chemical defenses in the Guam - tropical Pacific (e.g. BECERRO et al., 2003), Bermuda (e.g. MCCLINTOCK et al., 1997) and Caribbean sea (e.g. CHANAS; PAWLIK, 1995; PAWLIK et al., 1995), these investigations are absent in the South Atlantic region. However, the few examples reveals the potential of Brazilian sponge species to produce defensive chemicals against predators, such as the species Ircinia strobilina (EPIFANIO et al., 1999), and Geodia corticostylifera (CLAVICO et al., 2006). However, as well as in Caribbean coral reefs, several species of sponges are very abundant in the Brazilian coast, although greater part of the Brazilian marine sponges remains unknown (MURICY; SILVA, 1999).

The genus Hymeniacidon is widely distributed in the world. In Brazil it is restricted of the Southern and Southeast (LERNER et al., 2005; MURICY; HAJDU, 2006). They are frequently distributed in intertidal zone, including areas with chronic pollution, such as Guanabara Bay (Rio de Janeiro State), where Hymeniacidon heliophila (PARKER, 1910) is abundant (BREVES-RAMOS et al., 2005).

In species of Hymeniacidon genus the presence of peptides, alkaloids, and steroids has been identified (GRANATO et al., 2000; INABA et al., 1998; KOBAYASHI et al., 1996), but their function is still unknown. Chemicals from Hymeniacidon heliophila have been demonstrated to act as antibacterial, antioxidant and anti-apoptotic (MURICY; SILVA 1999; LYSEK et al., 2003) and its cells were successfully cultivated in cultures, producing even bioactive compounds (POMPONI; WILLOUGHBY, 1994; KLAUTAU et al., 1994).

The goal of this work was to investigate the defensive property of the extracts from the sponge $H$. heliophila against the tropical predators: hermit crabs, sea urchins and fishes.

\section{Material And Methods \\ Organisms and Collection Site}

Specimens of the sponge Hymeniacidon heliophila were collected by free diving in Itaipu beach, Niterói City, Rio de Janeiro State (2253'14"S $-43^{\circ} 22^{\prime} 48^{\prime}$ 'W, Fig. 1), where this species is abundant and occurs in intertidal zone. Sponges were frozen and lyophilized before extraction. Sea urchins (Lytechinus variegatus) and hermit crabs (Calcinus tibicen) were also collected in the same place.

$$
\text { Crude Extracts }
$$

Specimens of Hymeniacidon heliophila (75 g) were cut into small pieces and added to $n$-hexane in a graduated cylinder to measure the volume of tissue extracted $(200 \mathrm{ml})$. The three different extracts were obtained using solvents of increasing polarity CE1 $(n-$ hexane), CE2 (ethyl acetate), and CE3 (acetone/methanol 1:1).

$$
\text { Assays }
$$

Each extract was separately added into an artificial food in volumetrically appropriated level based on the volume of $H$. heliophila used in the extraction procedure, and offered to hermit crabs, sea urchins and fishes in choice feeding experiments together with untreated control food.

Assays with Calcinus tibicens and Lytechinus variegatus were based on the screen gel assay described in Hay et al. (1994). The artificial food consisted of $2.0 \mathrm{~g}$ of lyophilized powdered squid mantle and $0.4 \mathrm{~g}$ of carrageenan per $40 \mathrm{~m} 1$ of gel to prepare artificial food onto fiberglass window screening material, which supports the gel and provides an internal grid in which the amount of artificial food eaten can be quantified by counting the number of squares consumed. Before being stirred on the screening, the mix was heated in a microwave oven for $50 \mathrm{~s}$. Control gels were made in the same way, but without any extract. This gel was then poured on a plastic screen previously placed between a glass plate and a PVC mold. After the gel solidification, the 
mold was removed and the plastic screen was sliced into pieces $(10 \times 10$ squares, ca. 1 x $1 \mathrm{~cm}$ total $)$ containing a pair of food wafers. Control mix was poured into the screening material adjacent to the treatment gel. Each pair of food wafers (control and treatment) was offered to one specimen of $L$. variegatus and $C$. tibicens, and placed into a perforated plastic container. Each container was placed into a large aquarium system (ca. 100 1), and the bioassay was finished after the consumption of at least $30 \%$ of one of the food wafers. Crabs and sea urchins were maintained in a 1001 aquaria divided into 5 cells with 1 hermit crab in each with a constant flow of sand-filtered seawater. In fish tests, artificial food was also prepared with carrageenan, powdered squid, and distilled water, but with the use of food pellets as it was previously done in this type of assay (PAWLIK et al., 1995). The treatment was prepared by adding $0,9 \mathrm{~g}$ of powdered squid and $15 \mathrm{ml}$ of water to $0,4 \mathrm{~g}$ of carrageenan in order to yield a final volume of $20 \mathrm{ml}$ and produce a similar concentration of that found in $H$. heliophila. The mixture was vigorously stirred and poured on rectangular mold for pellet preparation (1.0 x $0.5 \times 0.5 \mathrm{~cm}$ each). Control pellets were made in the same way, but without the addition of crude extract.

Assays with generalist fishes were carried out in the field, at Enseada do Forno, Arraial do Cabo, Rio de Janeiro State (22 $\left.58^{\prime} 00^{\prime \prime} \mathrm{S}-42^{\circ} 00^{\prime} 47^{\prime \prime} \mathrm{W}\right)$. In natural assemblages of generalist fishes, the individuals were offered two options (control and treatment). Each trial set consisted of $n$ ropes containing a pair of pellets - one control and one treatment, that were attached to the sea bottom and exposed to generalist consumers during the necessary time to obtain any measurable consumption. After this period, the differential consumption between the remaining pellets (percent of mass eaten) was measured.

Statistical Treatment

Normality was verified using KolmogorovSmirnov test. Data obtained in percentage were arcsine transformed. $T$-test was used on dependent samples to evaluate all results. Assumptions of normality were accepted, and significant level was considered to be $\mathrm{p}$ $<0.05$.

\section{RESULTS}

In assay using Calcinus tibicen, both extracts CE1 and CE2 significantly inhibited this hermit crab ( $p<0.05$, Fig. 1), which reveals the existence of defensive features in both extracts. However, the extract CE3 was only effective as chemical defense against $C$. tibicen during the first 15 hours of experiment ( $p<0.001$, Fig. 1). After this time, no difference between the consumption of treated and control foods was observed $(p>0.05)$. The same extracts were tested against Lytechinus variegatus, but only CE1 was effective in inhibiting the consumption of this sea urchin ( $p>0.05$, Fig. 2). On the contrary, artificial foods prepared with the extracts CE2 and CE3 increased the consumption by $L$. variegatus when compared to their respective control foods, but not significantly ( $p>0.05$, Fig. 2).

From three extracts tested against generalist fishes, only CE2 showed a strong defensive property against consumption by this kind of fish $(p>0.05)$. Both extracts CE1 and CE3 did not inhibited these fishes $(p>0.05$, Fig. 3$)$.

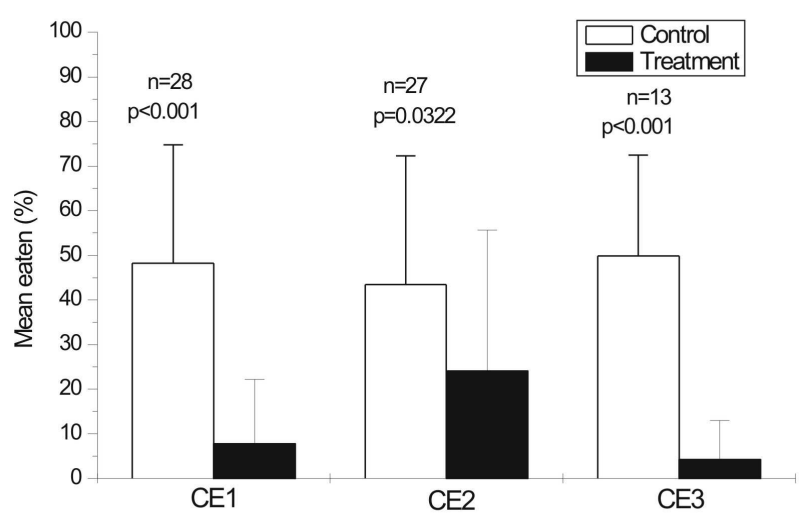

Fig. 1. Average consumption of artificial foods, control and treatment (with crude extracts of $H$. heliophila), by hermit crab Calcinus tibicen. Number of replicates indicated below columns, as $p$ value. The vertical bar above each column corresponds to the standard deviation. 


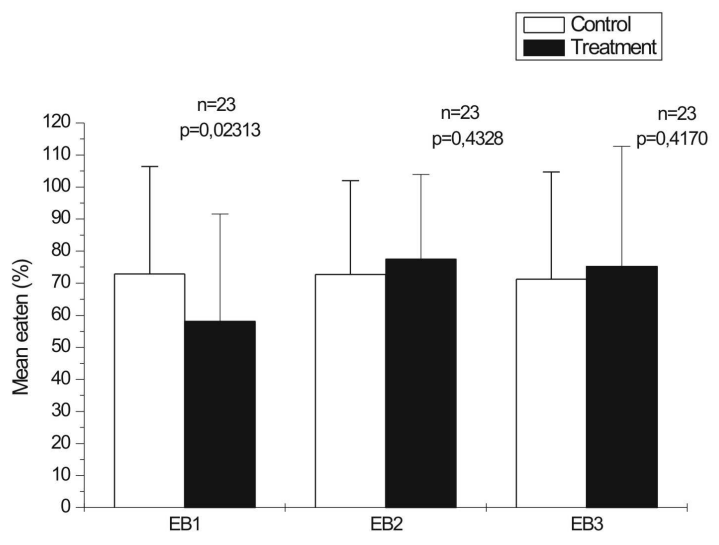

Fig. 2. Average consumption of artificial foods, control and treatment (with crude extracts of $H$. heliophila), by sea urchin Lytechinus variegatus. Number of replicates indicated below columns, as $p$ value. The vertical bar above each column corresponds to the standard deviation.

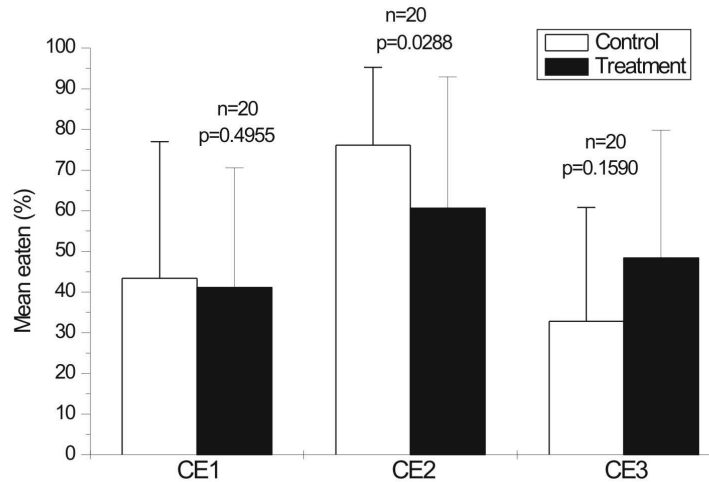

Fig. 3. Average consumption of artificial foods, control and treatment (with crude extracts of $H$. heliophila), by generalist fishes in situ. Number of replicates indicated below columns, as $p$ value. The vertical bar above each column corresponds to the standard deviation.

\section{Discussion}

All extracts used in experiments (high, medium and low polarities) were effective to inhibit the consumption by the hermit crab $C$. tibicen. However, the most polar extract, obtained with acetone/methanol, may be functional just in the first 15 hours of experiment probably due to its fast dissolution in aquarium water. On the other hand, both $n$-hexane and ethyl acetate extracts were effective as chemical defenses against this hermit crab during all experimental time, probably given to its low dissolution in seawater.
The hermit crab C. tibicen used in this work generally occurs together with $H$. heliophila in the intertidal zone of Itaipu beach and it could be an important predator of many sponges without chemical defenses. The defensive action of the three extracts of $H$. heliophila represents an important protection that might be due to different chemical classes of compounds. We do not know if these chemicals may act together and potentiate their effects (synergistic effect). Nonetheless, this work showed that chemicals from $H$. heliophila are efficient as a protection against predation by the hermit crab $C$. tibicen. 
Among the three different extracts, only one produced with $n$-hexane inhibited the consumption by the sea urchin $L$. variegatus. Sea urchins are important consumers of benthic organisms, especially algae, but it is also known that they predate high variety of invertebrates (RUPPERT; BARNES, 1994), including sponges (VANCE, 1979; AYLING, 1981; SANTOS et al., 2002). Apparently, the species $H$. heliophila has only non polar compounds that are associated to the inhibition of the feeding of the sea urchin $L$. variegatus. The sponge Hymeniacidon sp. from Red Sea has also chemical defenses against predation by the sea urchin Diadema setosum (BURNS et al., 2003). However, the extract tested was not separated by polarity levels. Thus, definition about the nature of substances involved in defensive process is not possible.

In general, two experimental approaches are considered to evaluate the defensive action of secondary metabolites in marine environment: sympatric and alopatric.

Sympatric approach considers the possibility of counter-adaptation by consumers living associated to organism producers of potential chemical defense (MCCLINTOCK; BAKER, 1997), whereas alopatric approach evaluates the extension of the defensive action (HAY, 1996). In the present work, sympatric approach was applied considering $L$. variegatus and $C$. tibicen, but as defensive action of the crude extracts was verified, we concluded that consumers did not develop characteristics to minimize this effect. In fact, the organisms' living in the same habitat is not enough, just the consumers that live directly or closely associated to hosts are known to consume them (HAY, 1992). For example, crabs of genus Libinia use the sponge $H$. heliophila to camuflate and avoid predation (STACHOWICZ; HAY, 2000). Opposite to that, individuals of $L$. variegatus, as well as $C$. tibicen, occur in the same habitat of $H$. heliophila, but not living in close association with this potential host. Considering our results, we can conclude that $H$. heliophila has efficient chemical defense system to protect itself against predation by both sympatric consumers, the sea urchin $L$. variegatus and the hermit crab C. tibicen.

In fish assays, only the medium polarity extract, obtained with extraction using ethyl acetate was effective to avoid predation by these vertebrates. During assays, the fish Stephanolepsis hispidus (family Monacanthidae) was frequently observed consuming artificial foods even though the defensive system of marine sponges is commonly associated to protection against fishes (PAWLIK et al., 1995; WILSON et al., 1999, ASSMANN et al., 2000). This species is abundant in Arraial do Cabo region and it is an omnivorous consumer (FERREIRA et al., 2004; FERREIRA et al., 2001).
Hydrophilic extract of sponge $H$. heliophila from United States coast was less consumed by generalist fish Lagodon rhomboides, whereas lipophylic extract was not efficient to deter consumption by this fish species (STACHOWICZ; HAY, 2000). The whole sponge (in natura) was also offered to $L$. rhomboides in assays and it was less consumed, about 10\% (STACHOWICZ; HAY, 2000). Crude extract of $H$. heliophila was also effective as a defense against the fish Thalassoma klunzingeri (BURNS et al., 2003). Curiously, in experiments with sea stars, $H$. heliophila was used as food before the tests with other sponges were initiated, revealing that H. heliophila do not have defenses against Echinaster echinophorus and E. sentus (WADDELL; PAWLIK, 2000a). These conflicting results reveal that chemical defenses are not absolute. They may vary in type (chemical structure) and concentration, depending on the site or predators evaluated (RUZICKA; GLEASON, 2008). As a consequence, effects of secondary metabolites appear to be determined by the specific effects of each compound on each species of consumer.

The decreasing of feeding caused by high (sea urchin, hermit crab), medium and low polarity extracts (fish, hermit crab) suggests that different classes of substances can be responsible for defensive action against consumers.

Different chemicals are known for $H$. heliophila. For example, the amino acid L-5hydroxytryptophan that exhibit antibiotic and antiapoptotic activity, even though it is not known if it acts as an inhibitor of predation (POMPONI; WILLOUGHBY, 1994; LYSEK et al., 2003). Besides, some steroidal compounds, such as cholesterol, colestanol, brassicasterol, 24-metilcolesterol, 24etilcolesterol were registered in $H$. heliophila (GRANATO et al., 2000). Broadly distributed among sponge species, the steroidal compounds may also be used in a defensive context. For example, the steroidal sulphated compounds amaroxocanes A and B inhibit the feeding of fishes (MORINAKA et al., 2009).

Nevertheless, secondary metabolites from $H$. heliophila have multiple functions against predation, which are independent from chemical nature. This multiplicity can be an advantage to reduce the amount of energy involved in production and/or storage of secondary metabolites. The deterrence in consume of distinct predators provide protection and it is advantageous to surviving of this species in high predation habitats, as tropical ones. More detailed chemical analysis are needed to elucidate which substances are involved in antipredation defensive system of $H$. heliophila. 


\section{ACKNOWLEDGEMENTS}

This work was supported by the Conselho Nacional de Desenvolvimento Científico e Tecnológico (CNPq), Coordenação de Aperfeiçoamento de Pessoal de Nível Superior (CAPES), and the Fundação de Amparo à Pesquisa do Estado do Rio de Janeiro (FAPERJ) through research grants. The authors are grateful to Juliana Ferrari, Camilla Oliveira Souza and Ecidine Alves Barbosa for their field assistance.

\section{REFERENCES}

ASSMANN, M.; LICHTE, E.; PAWLIK, J. R.; KOCK, M. Chemical defenses of the Caribbean sponges Agelas widenmayeri and Agelas conifera. Mar. Ecol. Prog. Ser., v. 207, p. 255-262, 2000.

AYLING, A. M. The role of biological disturbance in temperate subtidal encrusting communities. Ecology, v. 62, p. 830-847, 1981.

BECERRO, M. A.; THACKER, R. W.; TURON, X.; URIZ, M. J.; PAUL, V. J. Biogeography of sponge chemical ecology: comparisons of tropical and temperate defenses. Oecologia, v. 135, p. 91-101, 2003.

BJORNDAL, K. Digestibility of the sponge Chondrila nucula in the green turtle Chelonia mydas. Bull. mar. Sci., v. 47, p. 567-570, 1990.

BLUNT, J. W.; COPP, B. R.; HU, W.; MUNRO M. H. G.; NORTHCOTE, P. T.; PRINSEP, M. Marine natural products. Nat. Prod. Rep., v. 26, p. 170-244, 2009.

BREVES-RAMOS, A.; LAVRADO, H. P.; JUNQUEIRA, A. O. R.; SILVA, S. H. G. Succession in rocky intertidal benthic communities in areas with different pollution levels at Guanabara Bay (RJ-Brazil). Braz. Arch. Biol. Technol., v. 48, p. 951-965, 2005.

BURNS, E.; IFRACH, I.; CARMELI, S.; PAWLIK, J. R.; ILAN, M. Comparison of antipredatory defenses of Red Sea and Caribbean sponges. I. Chemical defense. Mar. Ecol. Prog. Ser., v. 252, p. 105-114, 2003.

CHANAS, B.; PAWLIK, J. R. Defenses of Caribbean sponges against predatory reef fish. II. Spicules, tissue toughness, and nutritional quality. Mar. Ecol. Prog. Ser., v. 127, p. 195-211, 1995

CIMINO, G.; DE ROSA, S.; DE STEFANO, S.; SODANO, G. The chemical defense of four Mediterranean nudibranchs. Comp. Biochem. Physiol., v. 73B, p. 471474, 1982.

CLAVICO, E. E. G.; MURICY, G.; DA GAMA, B. A. P.; BATISTA, D., VENTURA C. R. R., PEREIRA, R. C. Ecological roles of natural products from the marine sponge Geodia corticostylifera. Mar. Biol., v. 148, p. 479-488, 2006.

DUFFY, J. E.; PAUL, V. J. Prey nutritional quality and the effectiveness of chemical defenses against tropical reef fishes. Oecologia, v. 90, p. 333-339. 1992

EPIFANIO, R. de A.; GABRIEL, R.; MARTINS, D. L.; MURICY, G. The sesterterpene variabilin as fish feeding deterrent from Ircinia strobilina Lam. J. chem. Ecol., v. 25, p. 2247-2254, 1999.

FENICAL, W. 2006. Marine pharmaceuticals: Past, present, and future. Oceanography, v. 19, p. 110-119, 2006.
FERREIRA, C. E. L.; GONÇALVES, J. E. A.; COUTINHO, R. Community structure of fishes and habitat complexity on a tropical rocky shore. Environ. Biol. Fish., v. 61, p. 353-369, 2001.

FERREIRA, C. E. L.; FLOETER, S. R.; GASPARINI, J. L.; FERREIRA, B. P.; JOYEUX, J. C. Trophic structure patterns of Brazilian reef fishes: a latitudinal comparison. J. Biogeogr., v. 31, p. 1093-1106, 2004.

GRANATO, A. C.; BERLINCK, R. G. S.; MAGALHÃES, A.; SCHEFER, A. B.; FERREIRA, A. G.; SANCTIS, B.; FREITAS, J. C.; HAJDU, E.; MIGOTTO, A. E. Produtos naturais das esponjas marinhas Aaptos sp., Hymeniacidon aff. heliophila e do nudibrânquio Doris aff. verrucosa. Quím. Nova, v. 23, p. 594-599, 2000.

HAY, M. E. Seaweed chemical defenses: their role in the evolution of feeding specialization and in mediating complex interactions. In: PAUL V. J. (ed.). Ecological roles for marine secondary metabolites; explorations in chemical ecology series. New York: Cornell University Press, 1992. p. 93-118.

HAY, M. E. Marine chemical ecology: what's known and what's next? J. expl mar. Biol. Ecol., v. 200, p. 103134, 1996.

HAY, M. E.; KAPPEL, Q. E.; FENICAL, W. Synergisms in plant defenses against herbivores: interactions of chemistry, calcification, and plant quality. Ecology, v. 75, p. 1714-1726, 1994

HERB, R.; CARROLL, A. R.; YOSHIDA, W. Y.; SCHEUER, P. J.; PAUL, V. J. Polyalkylated cyclopentindoles: cytotoxic fish anti-feedants from a sponge, Axinella sp. Tetrahedron, v. 46, p. 3089-3092, 1990

INABA, K.; SATO, H., TSUDA, M.; KOBAYASHI, J. Spongiacidins A-D, new bromopyrrole alkaloids from Hymeniacidon sponge. J. nat. Prod., v. 61, p. 693-695, 1998.

KLAUTAU, M.; CUSTÓDIO, M.; BOROJEVIC, R. In vitro culture of primary cell lines from marine sponges. In: Van Soest, R. W. M.; van kempen T. M. G.; Braekman, J. C. (Ed). Sponges in time and space: biology, chemistry, paleontology. Rotterdam: AA Balkema, 1994. p. 401-406.

KOBAYASHI, J.; NAKAMURA, T.; TSUDA, M. Hymenanide F, a new cyclid heptapeptide from marine sponge Hymeniacidon sp. Tetrahedron, v. 52, p. 63556360, 1996

LERNER, C.; MOTHES, B.; CARRARO, J. L. Novos registros e ampliação de limites meridionais de distribuição de poríferos (Porifera, Demospongiae) no Atlântico sudoeste. Rev. Bras. Zool. v. 22, p. 596-612, 2005.

LYSEK, N.; KINSCHERF, R.; CLAUS, R.; LINDEL, T. L-5hydroxytryptophan: antioxidant and anti-apoptotic principle of the intertidal sponge Hymeniacidon heliophila. Z. Naturforsch., v. 58c, 568-572, 2003.

MAYER, A. M. S.; RODRIGUEZ, A. D.; BERLINCK, R.; HAMANN, M. T. Marine pharmacology in 2005-6: Marine compounds with antibacterial, anticoagulant, antifungal, anthelmitic, anti-inflammatory, antiprotozoal, and antiviral activities; affecting the cardiovascular, endocrine, immune and nervous systems and other miscellaneous mechanisms of action. BBA-GEN Subjects, v. 1790, p. 283-308, 2009. 
MCCLINTOCK, J. B.; BAKER, D. B. J. A review of the chemical ecology of shallow-water Antarctic marine invertebrates. Am. Zool., v. 37, p. 329-342, 1997.

MCCLINTOCK, J. B.; BAKER, B. J.; HAMMAN, M.; SLATTERY, M.; KOPITZKE, R. W.; HEINE. J. Tubefoot chemotactic responses of the spongivorous sea star Perknaster fuscus to organic extracts of antarctic sponges. J. chem. Ecol., v. 20, p. 859-870, 1994

MCCLINTOCK, J. B.; SWENSON, D.; TRAPIDOROSENTHAL, H.; BANGHART, L. Ichthyodeterrent properties of lipophilic extracts from Bermudan sponges. J. chem. Ecol., v. 23, p. 1607-1620, 1997.

. MORINAKA, B. I., PAWLIK, J. R.; MOLINSKI, T. F Amaroxocanes A and B: Sulfated dimeric sterols defend the Caribbean coral reef sponge Phorbas amaranthus from fish predators. J. nat. Prod., 72, p. 259-264, 2009.

MURICY, G.; HAJDU, E. Porifera brasilis. Guia de identificação das esponjas marinhas mais comuns do Sudeste do Brasil. Rio de Janeiro:Museu Nacional 2006, 104 p. (série Livros 17).

MURICY, G.; SILVA, O. Esponjas marinhas do Estado do Rio de Janeiro: um recurso renovável inexplorado. In: SILVA, S. H. G.; LAVRADO, H. P. (Ed.). Ecologia dos ambientes costeiros do Estado do Rio de Janeiro. Rio de Janeiro, 1999. (Oecol. Brasiliensis, v. 7, PPGE UFRJ, 1999, p. 156-178).

PARKER, G. H. The reactions of sponges, with a consideration of the origin of the nervous system. J. expl Zool., v. 8, p. 765-805, 1910

PAWLIK, J. R. A sponge-eating worm from Bermuda: Branchiosyllis oculata (Polychaeta, Syllidae). Mar. Ecol. P.S.Z.N.I, v. 4, p. 65-79, 1983.

PAWLIK, J. R.; KERNAN, M. R.; MOLINSKI, T. F.; HARPER, M. K.; FAULKNER, D. J. Defensive chemicals of the Spanish dancer nudibranch Hexabranchus sanguineus and its egg ribbons: macrolides derived from a sponge diet. J. expl mar. Biol. Ecol., v. 119, p. 99-109, 1988.

PAWLIK, J. R.; CHANAS, B.; TOONEN, R. J.; FENICAL, W. Defenses of Caribbean sponges against predatory reef fish. I. Chemical deterrency. Mar. Ecol. Prog. Ser., v. 127, p. 183-194, 1995

PENNINGS, S. C.; PABLO, S. R.; PAUL, V. J.; DUFFY, J. E. Effects of sponge secondary metabolites in different diets on feeding by three groups of consumers. J. expl Mar. Biol. Ecol., v. 180, p. 137-149, 1994.
POMPONI, S. A.; WILLOUGHBY, R. Sponge cell culture for production of bioactive metabolites. In: VAN SOEST, R. W. M.; VAN KEMPEN, T. M. G.; BRAEKMAN, J. C. (Ed.). Sponges in time and space: biology, chemistry, paleontology. Rotterdam: AA Balkema, p. 395- 400. 1994.

RANDALL, J. E.; HARTMAN, W. D. Sponge feeding fishes of the West-Indies. Mar. Biol. v. 1, p. 216-225, 1968.

ROGERS, S. D.; PAUL, V. J. Chemical defenses of three Glossodoris nudibranchs and their dietary Hyrtios sponges. Mar. Ecol. Prog. Ser., v. 77, p. 221-232, 1991.

RUPPERT, E. E.; BARNES, R. D. Invertebrate Zoology. 6th ed. Orlando, FL: Saunders College Publishing, Harcourt Brace and Company, 1994. 1100 p.

RUZICKA, R.; GLEASON, D. F. Latitudinal variation in spongivorous fishes and the effectiveness of sponge chemical defenses. Oecologia, v. 154, p. 785-794, 2008.

SANTOS, C. P.; COUTINHO, A. B.; HAJDU, E. Spongivory by Eucidaris tribuloides from Salvador, Bahia (Echinodermata: Echinoidea). J. mar. Biol. Assoc. U. K., v. 82, p. 295-297, 2002

STACHOWICZ, J. J.; HAY, M. E. Geographic variation in camouflage specialization by a decorator crab. The Am. Nat., v. 156 , p. $59-71,2000$

THOMPSON, J. E.; WALKER, R. P.; FAULKNER, D. J. Screening and bioassays for biologically-active substances from forty marine sponges from San Diego, California, USA. Mar. Biol., v. 88, p. 11-21, 1985.

VANCE, R. R. Diet foraging patterns of the sea urchin Centrostephanus coronatus as a predator avoidance strategy. Mar. Biol., v. 51, p. 251-258, 1979.

WADDELL, B.; PAWLIK, J. R. Defenses of Caribbean sponges against invertebrate predators. I. Assays with hermit crabs. Mar. Ecol. Prog. Ser., v. 195, p. 125-132, 2000a.

WADDELL, B.; PAWLIK, J. R. Defenses of Caribbean sponges against invertebrate predators. I. Assays with sea stars. Mar. Ecol. Prog. Ser., v. 195, p. 133-144, 2000b.

WILSON, D. M.; PUYANA, M.; FENICAL, W.; PAWLIK, J. R. Chemical defense of the Caribbean reef sponge Axinella corrugata against predatory fishes. J. chem. Ecol., v. 25, p. 2811-2823, 1999.

(Manuscript received 25 November 2009; revised 11 May 2010; accepted 28 July 2010) 